\title{
Doğal Kaynaklar Temelinde İç Çatışmaların Ekonomik Teorisi
}

\author{
The Economic Theory of Armed Civil Conflicts Based on Natural Resources
}

\author{
Yrd. Doç. Dr. Zelal Beyaz - Prof. Dr. Ibrahim Bakırtaş
}

\section{Öz}

II. Dünya Savaşinin sona ermesinden sonra, uluslararası savaşlardan daha yaygin hale gelmesine karşın, akademik çevre 1990'l yilların sonlarma kadar silahlı iç çatışma sorununa ilişkin çalı̧̧malara ağırlık vermemiştir. Bu tarihten itibaren yapılan pek çok çalışma doğal kaynaklar ile silahl içç çatışma veya iç savaş başlangicl, süresi ve şiddeti arasında bir ilişki olduğunu ileri sürmektedir. Literatürde doğal kaynaklar ile silahlı iç çatışma başlangıcı arasındaki ilişki altı farklı mekanizmayla açıklanmaktadır. Bunlar; açgözlü ayaklanma, dışarıdan müdahale, kindarlık, elverişlilik, zayıf devlet ve seyrek ticaret ağıdır. Mekanizmaların farklı önermeler üzerine inşa edilmiş olması hem terminolojik hem de kuramsal bir altyapının oluşturulmasını zorlaştırmaktadır Bazı kaynaklarda geçen teorilere diğer bazı kaynaklarda hiç yer verilmemesi ya da benzer teorilerin daha farkl, hatta bazen de çelişir șekilde kullanılması mevcut sorunu daha da büyütmektedir. Benzer şekilde farklı teorilerin sıralandiğı iddia edilen kaynaklarda da siralanan teorilerin birbiriyle iç içe oldukla$r$, kullanılan teorilerin birbirinin tekrarından öteye geçemedikleri ya da tamamlayıcı oldukları görülmektedir. Mevcut literatürdeki bu eksiklik ve zorluklar bu çalışmanın hazırlanmasındaki ana etkendir. Bu etken bağlamında bu çalısmanın iki amacı vardır. Bunun ilki, mevcut çalışmalar ışığında doğal kaynaklar ile iç çatışma başlangıcı arasındaki iliş̧kiyi iç çatışma mekanizmalar yardımıyla iktisadi olarak tanımlamaktır. İkinci amaç ise bu tanımlamalarla terminolojik eşgüdümün oluşturulmasına ve kuramsal altyapının şekillenmesine katkıda bulunmaktır.

Anahtar Kelimeler: Doğal Kaynaklar, Silahlı İç Çatışma, İç Savaş, Doğal Kaynakların Laneti.

\begin{abstract}
Scholars did not place any emphasis on the studies regarding the issue of armed civil conflicts or wars from the ending of World War II to the late 1990s, though they appeared to be more common than the international wars. A high number of studies from then on, however, have suggested that there is a relationship between the natural resources and the onset, duration and severity of the armed civil conflicts or wars. In literature, the relationship between the natural resources and armed civil conflicts is accounted for with six different mechanisms. These are greedy the rebels mechanism, the greedy outsiders mechanism, the grievance mechanism, the feasibility mechanism, the weak states mechanism and the sparse network mechanism. That these mechanisms are based on different propositions makes it difficult to form a terminological and theoretical substructure. The current problem is intensified by the fact that the theories in some sources are not mentioned at all in other sources or that similar theories are used in a more different and even conflicting way. Likewise, it is seen in the sources in which different theories are claimed to be listed that these theories concentric with each other and that the theories used are no more than the repetition of or just complementary to one another. It is these deficiencies or difficulties in the current literature that make the primary factor for the preparation of this study. In the sense of this factor, this study is intended for two purposes. The first purpose of the study is to make an economic definition of the relationship between the natural resources and the commencement of the civil conflict with the help of civil conflict mechanisms in the light of the existing studies. The second purpose of the study is to contribute to the formation of terminological coordination and the shaping of the theoretical substructure with these definitions.
\end{abstract}

Keywords:Natural Resources, Armed Civil Clash, Civil War, Curse of Natural Resources.

Yrd. Doç. Dr. Zelal Beyaz, Nişantaşı Üniversitesi, zelal.bengisu@nisantasi.edu.tr

Prof. Dr. İbrahim Bakırtaş, Aksaray Üniversitesi, ibakirtas@aksaray.edu.tr 


\section{Giriş}

Doğal kaynak zenginliği genellikle bir lütuf olarak kabul edilir. Bu genel kabule karşın çok sayıdaki örnek, özellikle petrol, elmas, doğal gaz gibi nitelikli doğal kaynakların onlara sahip olan toplumlar için bir felakete dönüşebildiğini göstermektedir. Bu paradoksal durum "Doğal Kaynakların Laneti” olarak adlandırılmaktadır. Doğal kaynaklar bir lütuf olmakla birlikte, çoğu zaman sahibi olan ülke için daha yavaş ekonomik büyüme, daha yüksek yoksulluk, daha yozlaşmış siyasi kurumlar ve daha yüksek silahlı iç çatışma veya iç savaş riski anlamına gelmektedir. Bu çalışmada bu paradoksal durumlardan sadece doğal kaynaklar ve iç savaşlar arasındaki ilişki incelenmektedir.

Doğal kaynaklar ile iç savaşlar arasındaki ilişki üzerine tartışmalar yeni değildir. Örneğin, 18. yüzyılda Malthus doğal kaynaklar üzerinden gerçekleşecek çatışmaların nüfus artışı ve çevresel bozulmanın bir sonucu olarak ortaya çıkacağını ileri sürmüştür. Bu tarihsel geçmişe ve uluslararası savaşlardan daha yaygın olmasına karşın, Karl (1997), Keen (1998) ve Collier ve Hoeffler (1998) gibi öncü isimlerin araştırmalarına kadar da üzerinde sistematik ve ampirik az sayıda çalışma yapılmıştır. Bu çalışmaların ortak bulgusu doğal kaynakların iç savaşların tetiklenmesinde, finansmanında ve sürdürülmesinde büyük öneme sahip olduğudur.

Günümüz iç savaşlarını anlamaya ve azaltmaya yönelik çalışmaların şekillenmesinde bu öncü çalışmalar ile Dünya Bankası’nın 1999 yılında başlattığı "Politik ve Kriminal Şiddetin Ekonomisi" adlı proje etkili olmuştur. Bu projenin nicel araştırma sonuçlarına göre fiili veya potansiyel doğal kaynakların iç savaşlar üzerinde istatiksel olarak anlamlı pozitif bir etkisi vardır. Literatürde doğal kaynaklar ile iç savaş başlangıcı arasındaki ilişki altı farklı mekanizmayla açıklanmaktadır. Bunlar; açgözlü ayaklanma, dışarıdan müdahale, kindarlık, elverişslilik, zayıf devlet ve seyrek ticaret ağıdır. Mekanizmaların farklı önermeler üzerine inşa edilmiş olması hem terminolojik hem de kuramsal bir altyapının oluşturulmasını zorlaştırmaktadır. Bazı kaynaklarda geçen teorilere diğer bazı kaynaklarda hiç yer verilmemesi ya da benzer teorilerin daha farklı, hatta bazen de çelişir şekilde kullanılması mevcut zorluğu daha da büyütmektedir. Benzer şekilde farklı teorilerin sıralandığı iddia edilen kaynaklarda da sıralanan teorilerin birbiriyle iç içe oldukları, kul- lanılan teorilerin birbirinin tekrarından öteye geçememektedir. Bu çalışma mevcut literatürdeki eksiklik ve zorluklara ilişkin tespitin bir ürünüdür.

Bu çalışmanın iki amacı vardır. Birincisi, mevcut çalışmalar ışı̆̆ında doğal kaynaklar ile iç savaş başlangıcı arasındaki ilişkiyi iç savaş mekanizmaları yardımılla iktisadi olarak tanımlamaktır. İkinci amaç ise bu tanımlamalarla terminolojik eşgüdümün oluşturulmasına ve kuramsal altyapının şekillenmesine katkıda bulunabilmektir. Çalışma giriş bölümünü takip eden üç bölümden oluşmaktadır. Birinci bölümde temel kavramlara ve bunlar arasındaki ilişkinin varlığına işaret eden örneklere yer verilmektedir. İkinci bölümünde ise ayaklanma, iç savaş ve doğal kaynaklar arasındaki ilişkiyi açıklayan alternatif mekanizma yaklaşımları açıklanmaktadır. Çalışmanın son bölümünde ise mekanizmalar temelinde, günümüz iç çatışmaları da dikkate alınarak, bir genel değerlendirme yapilmaktadır.

\section{Çatışma, Ayaklanma, Silahlı İç Çatışma ve Doğal Kaynaklar}

Sosyal bilimlerdeki pek çok kavram gibi "çatışma" kavramı da farklı anlamları olan ve bazı kavramlarla eş anlamlı gibi düşünebilen, açık uçlu bir içeriğe sahiptir. Boulding (1963:7) çatışmanın ekonomik alanda ekonomik örgütler arasında, politika alanında devletler ve/veya örgütler arasında, antropolojide ise kültürler arasında, kısaca insanın olduğu her yerde ortaya çıkan bir olgu olduğunu ifade etmektedir.

Sosyolojik açıdan çatışma, bireylerin ya da grupların, ekonomik ve politik hedeflerinin, değer yargılarının ve normlarının çakışması ve ayrışması üzerinden yaşadıkları mücadele, kavga veya savaştır (Marshall, 1999, s.111). Siyaset sosyolojisi önceleri çatışmayı sadece kültür odaklı konumlandırırken, günümüzde sınıfsal pozisyonların, statü tanımının, ideolojik tutumların, etnik veya dinsel benlikler üzerinden kendilerini tanımlayan grupların güç mücadelesinin farklılaşması veya uzlaşmaması üzerinden çatışmaların yaşandığını ileri sürmektedir. Sosyal psikolojide ise farklı ekoller çatışmayı, ekonomik, kimliksel ya da politik olan bağdaşmaz hedef, davranış, amaç ve inançların çakışması ve ayrışması olarak tanımlamaktadır (Lee, Ashmore ve Wilder, 2001, s.6). 
Uluslararası hukuk literatüründe çatışma daha çok silahlı çatışmalar için kullanılmaktadır. Uluslararası hukuk açısından çatışma, tarafların potansiyel tutum ve durumlarının bağdaşmaması veya gelecekte de bağdaşmayacağının öngörülmesiyle güç, kaynaklar, çıar ya da değerler üzerinden avantajlı duruma gelme amacindaki grupların arasında rekabetin giderek artması, ayrıca taraflardan en az birinin ilişkilerinin bağdaşmayacak amaçlar üzerinden yürüdüğü inancinda olmasıdır (Mengiler, 2005, s.17).

Çatışma analizi ve barış çalışmaları literatüründe çatışma, kaçınılmaz öz çıkarlar, değerler ve inançlar üzerinden verilen mücadele, kavga ve bazen de tepkisel ayrışma olarak tanımlanmaktadır (Mial vd., 2007, s.7). Bu bağlamda Jeong (2008:13) çatışmayı sinmiş, olan kişiler, gruplar ya da uluslararası düzeyde benzeşmeyen, ayrışan farklı değerler ve çıkarlar üzerindeki rekabeti temsil eden yapısal (ekonomik ilişkiler, iktidar mücadelesi, kültürel baskınlık ve kimliğin ve kimliğin tanınması gibi) ve psikolojik (değer uyuşmazlığı ve önyargıların) etmenlerin de etkisiyle verilen mücadeleler olarak tanımlamaktadır. Burton (1997:5) ise normlar, ilişkiler, diğer devlet, grup ya da kişilerin farklı konularda karar vermelerini etkileme veya somut hedefler üzerinden yapılan meydan okuma, hatta yok etmeye kadar varabilecek mücadeleleri çatışma olarak nitelendirmektedir.

Bir devletin içindeki çatışmaları tanımlamak için kullanılan "iç savaş" ve "toplumsal çatışma" gibi kavramlar sıkça benzeşmekte ve zaman zaman birbirlerinin yerine kullanılmaktadır. Buna karşılık kullanımları açısından tanımlamalar incelendiğinde iç savaş daha çok bir ya da birden çok grubun farklı nedenlerle mevcut devlet otoritesine karşı ya da devlet otoritesinin yıkıldığı durumlarda gruplar arası yapılan çatışmalar olarak tanımlanmaktadır. Toplumsal çatışma ise toplum içindeki grupların farklı sebepler üzerinden yaptıkları çatışmaları tanımlarken, toplumsal çatışmaların yarattığı kargaşa ortamı devle otoritesini yok ederek, ikinci bir evre olan iç savaşa dönüşmektedir (Evans ve Newnham, 2007, s. 606-607).

Farklı terimlerle ifade edilmelerine karşılık tüm tanımlar benzer anlamlar içermektedir. Benzer durum, kavramın İngilizcesi için de geçerlidir. Kelimenin İngilizce farklı karşılıklarının, çoğunlukla benzer veya aynı anlamda kullanıldıklarını görmek mümkündür. "Conflict, dispute, clash, struggle" gibi kelimelerin birbirleri yerine kullanıldığı; "conflict" kelimesinin ise her zaman şiddet içeren çatışmaları ifade etmediği görülmektedir. Ancak bu çalışmada "çatışma", "şiddet içeren çatışma" anlamında kullanılacaktır.

Geleneksel uluslararası hukukta silahlı iç çatışmalar, devletin silahlı güçleri ile ülke içindeki bir veya birden fazla muhalif grup arasında veya bu muhalif grupların arasında yaşanan çatışmalardır (Öğ̈̈t, 2013, s.9). Geleneksel uluslararası hukukta silahlı iç çatışmaların gelişiminde çatışmanın ölçüsüne ve yoğunluğuna bağlı olarak üç farklı aşama söz konusudur. Bu aşamalar, başkaldırı (rebellion), ayaklanma (insurgency) ve savaş halidir (belligerency) (Cullen, 2005, s.69). Başkaldırı, bir devlet otoritesine yönelik kısa süreli ve münferit bir tehdittir (Wilson, 1988, s.23). Yasal devlete ya da hükümete karşı başlatılan silahlı başkaldırının bastırılamaması ve çatışmanın başkaldırıdan daha önemli ve sürekli hale gelerek nitelik değiştirmesi durumunda, bu de facto durumun tescili anlamında muhalif topluluklara "ayaklanan" statüsünün tanınması söz konusudur (Lootsteen, 2000, s.113). Hukuksal açıdan savaşan taraf statüsünün tanınması ise ayrılma ya da hükümet olma amacıyla bir devlet ve hükümetine karşı başkaldıran ancak bağımsız bir devlet olarak tanınmasina yetecek kadar kesin bir takım koşulları yerine getirmeleri durumunda, yalnızca bu kuvvet kullanma döneminde geçerli olmak üzere, ülke devletinin ya da üçüncü devletlerin verdiği bir statüdür (Pazarcı, 1994, s.289-290).

Politik iktisat literatüründe silahlı iç çatışmalar genellikle temel dört kategoriye ayrılmaktadır. Bunlar yönetimdeki koalisyonu devirmeyi ya da diğer yollarla siyasal rejimi değiştirmeyi amaçlayan, genellikle askeri darbeler ve halk devrimlerine dönüşen hükümet çatışmaları (governmental conflicts); devletin içindeki belirli bir bölgenin kontrolüyle ilgili olan ayrılıkçı çatışmalar (seccesionist conflicts), etnik çatışmalar (ethnic conflicts) ve uluslararasılaşmış silahlı iç çatışmalardır (internationalized armed civil conflicts).

Siyaset bilimci Gleditsch vd. (2002) çatışmaları iki temel boyutta ele almaktadırlar. Araştırmacılar silahlı çatışmaları ilk olarak katılımcılarına ve konumlarına göre ikiye ayırmaktadırlar. Katılımcılarına ve konumlarına göre çatışmalar, taraflardan birinin devlet olduğu, devlet ile silahlı grup arasında ülke sınırları içinde yaşanmayan "ülke dışı (extrastate) silahlı çatışmalar”; iki veya daha fazla devlet arasında yaşanan 
"devletlerarası silahı çatışmalar"; bir ülkenin hükümeti ile ülke içindeki muhalif bir grup veya gruplar arasında yaşanan "silahlı iç çatışmalar" ve uluslararasılaşmış silahlı iç çatışmaları kapsamaktadır. İkinci olarak çatışmaları şiddetin düzeyine göre üç farklı gruba ayırmaktadırlar. Bunlar bir yıl içinde en az 25 kişinin ve çatışma sonucunda toplamda en çok 1.000 kişinin hayatını kaybettiği "küçük silahlı çatışmalar (minör armed conflicts)", bir yıl içinde en az 25 ve çatışma sonucunda toplamda en az 1.000 kişinin hayatını kaybettiği "orta seviye çatışmalar (intermediate armed conflicts) $)^{1 "}$ bir yll içinde en az 1.000 kişinin hayatını kaybettiği "savaşlar"dır.
Şekil 1, katılımcılarına ve konumlarına göre silahlı çatışmaların 1946-2015 dönemindeki trendini göstermektedir. Şekil 1 incelendiğinde 1946-2015 döneminde devletlerarası çatışmaların sayısında ciddi bir azalma olduğu görülmektedir. Ülke içi silahlı çatışmaların sayısının ise 1990'lı yılların başında en yüksek düzeye ulaştığ karşın 2014 yılında bu çatışmaların sayısının zirveye yaklaştı̆̆1 görülmektedir. Uluslararasılaşmış silahlı çatışmaların sayısı 1946-2012 döneminde nispeten sabit kalmışsa da 2015 yılında zirveye ulaşmıştır. Şekil 1'de son yıllardaki çatışmaların büyük bir çoğunluğunun ülke içi silahlı çatışmalar olduğu görülmektedir.

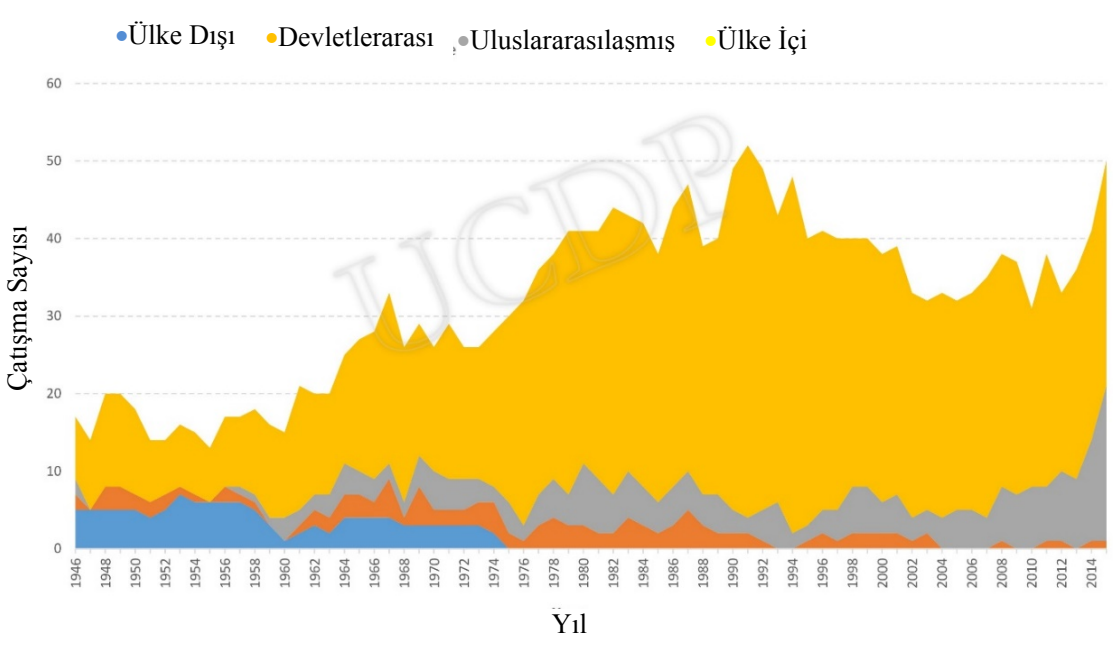

Kaynak: http://www.pcr.uu.se/digitalAssets/595/c_595102-1_1-k_type_jpg.jpg, (Erişim Tarihi: 07.12.2016).

Şekil 1. Katılımcılarına ve Konumlarına Göre Silahlı Çatışmaların Trendi, 1946-2015

Şekil 2., şiddetin düzeyine göre silahlı çatışmaların 1946-2015 dönemindeki trendini göstermektedir. Şekil 2 incelendiğinde 1946-2015 döneminde küçük silahlı çatışmalar ile savaşların birbirine yakın bir trend izlediği görülmektedir. 1990’lı yılların başında hem küçük silahlı çatışmalar hem de savaşlar zirveye ulaşmıştır. Son yıllardaki çatışmaların büyük bir çoğunluğu ise bir yıl içinde en az 1.000 kişinin hayatını kaybettiği savaşlardır.

1 Ancak orta seviyeli çatışmalar, her hangi bir yıl içinde çatışma sonucunda hayatını kaybeden kişi sayısının 1.000'i aşmadığı çatışmalardır. 


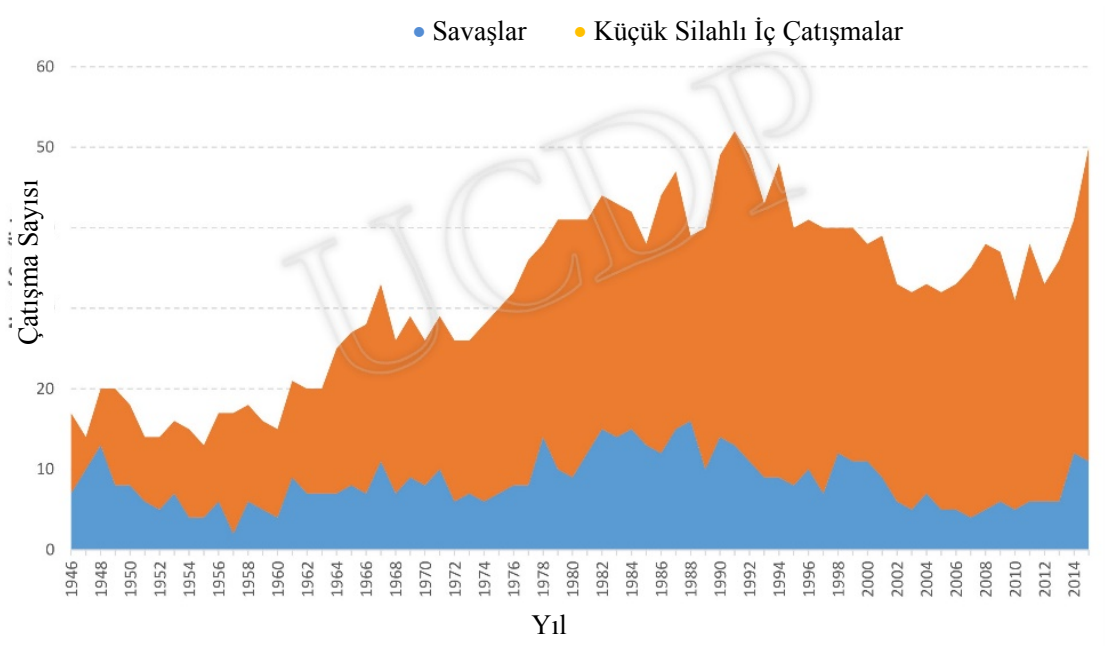

Kaynak: http://www.pcr.uu.se/digitalAssets/595/595102_lintensity-jpg.jpg, (Erişim Tarihi: 07.12.2016).

\section{Şekil 2. Şiddetin Düzeyine Göre Silahı C Çatışmaların Trendi, 1946-2015}

Çatışmaları tanımlamak için bir eşik kriteri olarak mutlak ölen kişi sayısı yaygın olarak kullanılmaktadır. Çatışma sonucunda ölen kişi sayısının ülkenin nüfusuna oranına göre çatışmaların sınıflandırılması gibi göreceli eşikler ise nadiren kullanılmaktadır. Büyük ülkelerde birkaç kişinin ölümü bir iç savaş olarak yorumlanmazken, az nüfusa sahip ülkelerde birkaç kişinin ölümü bile bir iç savaş olarak yorumlanabilmektedir. Göreceli bir eşiğin kullanılması yoğunlukları açısından büyük ölçüde farklılık arz eden çatışmaların sınıflandırılmasını sağlayacaktır. Diğer taraftan bazı veri setleri çatışmaları öncelikli olarak şiddete göre değil çatışmanın temel sorunlarına göre tanımlamaktadır (Collier ve Hoeffler, 2001, s.5).

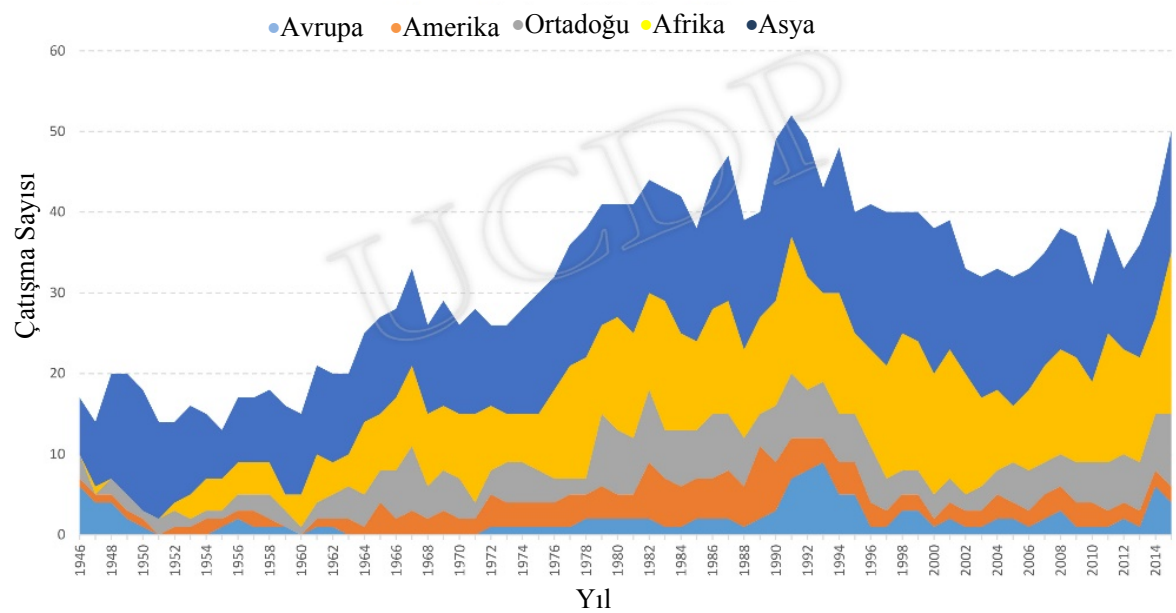

Kaynak: http://www.pcr.uu.se/digitalAssets/595/595102_1region_jpg.jpg,

Şekil 3. Silahlı Çatışmaların Coğrafi Trendi, 1946-2015 
Şekil 3., 1946-2015 yılları arasında yaşanan silahlı çatışmaların coğrafi trendini göstermektedir. Şekil 3 incelendiğinde Avrupa'da ve Amerika'da yaşanan silahlı çatışmaların sayısında ciddi bir azalma olduğu görülmektedir. Avrupa'daki çatışmaların sayısı Balkanlardaki iç çatışmalar nedeniyle 1990'ların başında zirveye ulaşmıştır. Orta Amerika ve Güney Amerika'daki birçok ülkeyi etkileyen Amerika'daki silahlı çatışmalar 1980'lerde doruğa ulaşmıştır. 1980'li yıllarda ve 2010 yllından sonra bir miktar artış sergileyen Orta Doğu'daki çatışmaların sayısı 1946-2015 yılları arasında nispeten sabit kalmıştır. Şekil 3 incelendiğinde son yıllardaki çatışmaların büyük çoğunluğunun Asya ve Afrika'da yaşandığı görülmektedir.

\section{Alternatif Mekanizmalar}

İç savaşların ortaya çıkış nedenlerini sorgulayabilmek için öncelikli olarak bu çatışmalara ortam hazırlayan ayaklanmaları incelemek gerekir. Siyaset bilimcilere göre ayaklanmalar etnik düşmanlık, politik baskılama veya eşitsizlik gibi nedenlerden; ekonomistlere göre ise mevcut kisitlar altında, fayda temelinde grupların tercihlerindeki farklılıklardan kaynaklanmaktadır. Ayaklanmaların geleneksel iktisadi analizinde cevabı aranan sorular, isyancıları güdüleyen unsurların neler olduğu ve ayaklanma sürecinde beklentilerinin ne olduğudur. Bir ayaklanmanın en önemli kısıtının finansman olduğu düşünüldügünnde, sorular daha da önemli hale gelmektedir (Collier ve Hoeffler, 2002a, s.16).

Soğuk Savaş döneminde çoğu isyancı grubun ABD, Sovyetler Birliği ve Fransa gibi dış güçler tarafından finanse edildiği bilinmektedir. Ancak Soğuk Savaş sonrasında isyancılar kendilerini finanse etmek için başka yollar aramıştır. Bu konuda onlara yine gelişmiş ve emperyal ülkeler rehberlik etmiş ve kazan kazan kuralına göre oluşturdukları şerde işbirliği felsefesiyle bu isyancıları doğal kaynakları elde etme ve kontrol etme konularında ikna etmişlerdir (Keen, 1998, s.37). Bu grupların iki nedenden dolayı ikna edilmiş olabileceği ileri sürülmektedir. Birincisi, doğal kaynakların büyük rantlar yaratabilmesidir. İkincisi, doğal kaynakların üretimlerinin belirli bir yere bağlı olması ve üretim yerlerinin kolayca değiştirilememesidir. Doğal kaynak şirketlerinin, özellikle maden şirketlerinin, yağmalanma veya gasp edilme riskine açık olması ve maden firmalarının genellikle isyancı gruplara haraç ödedikten sonra bile kar edecek kadar yüklü miktarda gelir etmesi, doğal kaynakları isyancı gruplar için ideal bir gelir kaynağına dönüştürmüştür (Ross, 2003a, s.18). Doğal kaynaklar isyancıların sürekli hale getirdikleri ayaklanmaların bir çatışmaya dönüşmesinde ihtiyaç duydukları finansman gereksiniminin önemli bir kısmını tek başına karşılayabilmektedir. DEAŞ’ın Suriye ve Irak'taki varlığını korumasında ve iç savaşın devam ettirilmesinde petrol kilit rol oynamaktadır.

Literatürde doğal kaynaklar ile iç savaş başlangıcı arasındaki ilişkiyi açıklayan altı farklı mekanizma vardır. Bunlar; açgözlü ayaklanma mekanizmaları, dışarıdan müdahale mekanizması, kindarlık mekanizmaları, elverişlilik mekanizması, zayıf devlet mekanizmaları ve seyrek ticaret ağı mekanizmasıdır. Bu mekanizmalar aşağıda açıklanmaktadır.

\section{Açgözlü Ayaklanma Mekanizmaları}

Collier ve Hoeffler $(1998,2000)$ ileri sürdükleri Açgözlü Ayaklanma Mekanizmaları (Greedy Rebel Mechanisms) argümanında, iç savaşlara neden olan unsurların yalnızca politik veya sosyal kindarlıklar olmadığını ileri sürmektedir. Bu argümana göre iç savaş ayaklanma boyunca suç benzeri yağmalama faaliyetlerinden elde edilebilecek özel ve kamu gelirlerinin kontrolünün ele geçirilmesiyle daha çoğuna sahip olma mantığına dayanan "açgözlülük" tarafından motive edilmektedir (Collier ve Hoeffler, 2002a, s.15). Doğal kaynağın yağmalanabilir olması durumunda isyancılar ganimet arayışı davranışı olarak adlandırılan doğal kaynağı elde etme faaliyetlerine girişeceklerdir. İ́syancıların doğal kaynakları doğrudan kontrol etmeleri de gerekmemektedir. Bazı durumlarda isyancıların söz konusu kaynakları işleten firmalardan rant sağlamaları daha etkili bir yol olabilmektedir (Humphreys, 2005, s.511). Özetle, açgözlülük modeli iç savaşın finansman kaynaklarına odaklanmaktadır. Açgözlü ayaklanma mekanizmaları argümanı temelinde motivasyon unsurlarına göre üç ayrı yaklaşım üzerinden detaylandırılmaktadır. Bunlar; devleti ele geçirmenin ödülü, suç benzeri faaliyetler ve ayrılıkçı hareketlerdir.

Devleti ele geçirmenin ödülü yaklaşımında doğal kaynaklar devleti ele geçirmenin değerini yükseltmektedir. Özellikle petrol gibi değerli minerallerin üretimi, devletin zenginliğinin arttırdığından, doğal kaynak 
zengini ülkelerdeki hükümetler doğal kaynaklardan yoksun ülkelerdeki hükümetlerden daha cazip hedefler haline getirmektedir (Englebert ve Ron, 2004; Fearon, 2005; ${ }^{1}$ Le Billon, 2001). Bu yaklaşımın öncü isimlerinden, Fearon ve Laitin'e (2003) göre açgözlülük ve doğal kaynakları elde etme imkanı isyancılar için bir motivasyon unsurudur. Ancak Collier ve Hoeffler (2000)'in aksine bu motivasyonun devlet kontrolünü ele geçirmeyi sağlama teşebbüsü üzerinden işlediğini ileri sürmektedir. Çad Cumhuriyeti ve Kongo Cumhuriyeti örneklerinde olduğu gibi, isyancı grupların amacı doğal kaynakların sahibi olan devletin kontrolünü ele geçirmektir (Ross, 2004b, s.280). Devlete önemli ölçüde gelir sağlayan bu doğal kaynakların ele geçirilmesi düşüncesi iç savaş konusunda isyanciları motive etmektedir.

Suç benzeri faaliyetler yaklaşımında ise rasyonel tercihler varsayımı altında, iç çatışmaların güdüleyicisi yağmalama faaliyetleridir (Collier ve Hoeffler, 1998; Collier, 2000). Bu yaklaşıma göre ülke sınırları içindeki gruplar bağımsızlık kazanmak için doğal kaynaklardan faydalanarak suç benzeri faaliyetlere karışmaktadır. Şiddet olaylarına teşebbüs eden bu grupların büyük kısmının temel amacı siyasidir. İsyancı grupların başlangıçtaki amacı yalnızca finansman ihtiyacını karşılamak için suç faaliyetlerine girişmektir. Ancak zamanla suç faaliyetlerini içeren günlük görevler, farkına varmaksızın, örgüte bir hareket kabiliyeti kazandırmaktadır. Böylece örgütün karakteristik yapısı yavaş yavaş değişmektedir (Collier vd., 2003, s.79). Örneğin, elmaslar bazı iç savaşlarda gerillaların en iyi arkadaşıdır. Bu örnek dikkate alındığında, iç savaşlar kindarlıktan ziyade ekonomik fırsatlardan kaynaklanmaktadır (The New York Times, 16 Haziran 2000). Çatışma elmaslarını ${ }^{2}$ ticaretini sonlandırmak için BM tarafından desteklenen ve 2000 yılının Mayıs ayında başlayan Kimberley Süreci ${ }^{3}$, suçun güdüleyicisi olan bu unsurlarla mücadeleyi amaçlamaktadır. $\mathrm{Bu}$ yaklaşıma göre bir suç faaliyetiyle başlayıp, ayaklanmalara dönüssse de ve ayaklanmalar her ne kadar suç ile benzer nitelikler taşısa da ikisi arasında dört

2 “Çatışma elmasları" terimi BM tarafından "isyan hareketlerinin meşru hükümetleri zayıflatmak veya devirmek için giriştikleri askeri faaliyetleri finanse etmek için kullandıkları ham elmaslar" olarak tanımlanmıştır. Bkz; United Nations General Asi sembly Resolution 55/56, December 1, 2000 (A/RES/55/56).

3 İki yıl uygulama imkânı bulan bu süreç, isyancı grupların işlenmemiş elmasları küresel piyasalarda satışını zorlaştırmak için tasarlanmıștı. temel fark bulunmaktadır. Birincisi, ayaklanmanın ortaya çıkışı ile gelir düzeyi arasında güçlü bir ilişki vardır. Zengin toplumların silahlı iç çatışmayla karşılaşma riski yoksul toplumlardan daha düşüktür. Buna karşın zengin toplumların şiddet suçu olaylarılyla karşlaşma riski yoksul ülkelerden farklılaşmamaktadır. İkincisi, artan gelir dağılımı eşitsizliği iç çatışma riskini arttırırken; artan gelir dağılımı eşitsizliğinin şiddet suçlarıyla ilişkisi tartışmalıdır. Üçüncüsü doğal kaynak ihracatı ile iç çatışma riski arasında güçlü bir ilişki söz konusudur. Doğal kaynak ihracatı ile şiddet suçları arasındaki ilişki literatürde sorgulanmamıştır. Dördüncüsü, ayaklanmalar doğrudan olmasa bile bir şekilde kindarlıkla, grup kimliği ile ilişkilendirilirken, şiddet suçlarında grup kimliği etkili değildir (Collier, 2000a, s.840).

İç ayaklanma mekanizmalarına ayrılıkçı hareketler yaklaşımına göre, çatışmaların nedeni petrol, elmas vb. değerli doğal kaynaklardır (Ross, 2003a, s.12). $\mathrm{Bu}$ yaklaşıma göre, doğal kaynak zenginliği, kaynak zengini bölgelerde yaşayan insanlara ayrı bir devlet kurmak için ekonomik bir teşvik sunmak yoluyla, ayrılıkçı hareketleri tetikleyerek iç savaşlara neden olabilmektedir (Le Billon, 2001; Collier ve Hoeffler, 2002c; Fearon, 2002). Bu yaklaşıma göre doğal kaynak zenginliği, kaynak zengini bölgelerde bağımsızlı̆̆ın öngörülen faydalarını arttırmak veya bağımsızlığın görünürdeki maliyetlerini düşürerek ayrılıkçı hareketleri motive etmektedir. Bu motivasyon iç savaşlara neden olabilmektedir. Doğal kaynak temelli ayaklanmalardan mustarip olan bölgeleri diğer bölgelerden ayıran üç temel özellikler vardır. Birincisi, doğal kaynak zengini bölgelerde yaşayanlar ülkenin geri kalanından farklı etnik, dilsel veya dinsel kimliğe sahiptir. İkincisi, yöre sakinlerinin sahip oldukları arsaların istimlak edilmesi, çevresel zararlar ve ülkenin diğer bölgelerinden bu bölgeye iş gücü hareketliliği gibi doğal kaynağın çıkarılmasıyla ilgili sorunlarla karşı karşıyadır. Üçüncüsü bu bölgenin sakinleri, merkezi hükümetin kendilerine ait zenginlikleri haksız şekilde sahiplendiğine ve ayrı bir devlete sahip olmaları durumunda daha zengin olacaklarına inanmaktadır ya da inandırılmıştır (Ross, 2003a, s.15).

Dışarıdan Müdahale (Açgözlü Dış) Mekanizması Dışarıdan müdahale (açgözlü dış) mekanizmasına göre doğal kaynak zengini bir devletin paydaşı olmayan devlet veya yabancı şirketler iç ayaklanmalara 
destek vererek ve taraf olarak iç savaşı güdülemektedir. Dış güçler doğal kaynak zenginliklerine erişmek için doğal kaynak zengini ülkelerde hükümete karşı ayaklanan isyancı grupları desteklemektedir (Ross, 2004a, s.56). Demokratik Kongo Cumhuriyeti, Sierra Leone ve Kongo Cumhuriyeti gibi çok sayıda ülkede iç savaşların ortaya çıkmasının veya tırmanmasının nedenlerinden biri başka devletlerin ve yabancı şirketlerin hammaddeye dolaylı yoldan erişmek ve sahip olmak istekleridir (Dashwood, 2000; Meldrum, 2000).

Demokratik Kongo Cumhuriyeti’nde 1990'lı yllarda başlayan iç savaşta karışıklıkların merkezi zengin elmas ve altın madenlerine sahip Kasai ve Kivu eyaleti ile petrol yataklarına sahip Ituru eyaleti olmuştur. Ülkedeki ayrılıkçı hareketlerin güçlenmesinde önemli rol oynayan aktörlerden biri bu bölgede ekonomik faaliyetler yürüten yabancı şirketleridir. Örneğin; Katanga bölgesinin bağımsızlı̆̆ı için hareket eden gruplar, Union Miniere du Haute-Katanga, Campaigne du Katanga, Societe Minirale de Belgique gibi şirketlerden yardım almıştır (İnat ve Gieler, 2007, s.421). Benzer şekilde Fransız petrol şirketi olan Elf de, ülkedeki iç çatışmanın tırmanmasına neden olan bir takım faaliyetlere destek olmuştur (Humphreys, 2005, s.511).

Demokratik Kongo Cumhuriyeti'ndeki iç çatışmalarda, ülkenin sahip olduğu doğal kaynak zenginliğinden ötürü, komşu devletler de çatışmalarda taraf olmuştur. Hem 1996 hem de 1998 yılında yaşanan iç savaşlar boyunca Ruanda, Uganda, Angola, Zimbabwe ve diğer komşu ülkeler bu ülkenin doğal kaynak zenginliğinden büyük miktarda yararlanmıştır. BM Bilirkişi Heyeti (2001)'ne göre Uganda’nın Demokratik Kongo Cumhuriyeti’ndeki savaşa girme kararının altında Ugandalı bir takım çıkar gruplarının ülkenin doğal kaynaklar bakımından zengin bölgelerini kullanma isteği yatmaktadır. Ruanda hükümeti ise doğal kaynakların yağmalanması sonucu elde edilecek rantın işgal maliyetlerini karşılayacağına olan inancı nedeniyle bu savașa dâhil olmuștur. Ruanda ordusu Demokratik Kongo Cumhuriyeti'ne girdikten sonra ülkede çıkardığı yer altı kaynaklarını askeri müdahalesinin finansmanında kullanmıștır (UN Panel of Experts 2001, 2002). Zimbabve ordusu ve kabine üyeleri ise mineral varlıkların ticaretinden fayda sağlamak amaciyla Demokratik Kongo Cumhuriyeti'ndeki çatışmada yer almıştır (Dashwood, 2000; Meldrum, 2000).

\section{Kindarlık Mekanizmaları}

Collier ve Hoeffler (2002a), Humphreys (2003) ve Lujala (2010) gibi bazı araştırmacılar doğal kaynakların refah etkisinin dağılımındaki adaletsizliğin kin duygusunu artırabileceğini ve bu duygunun iç savaşları motive edebileceğini ileri sürmektedir. Doğal kaynaklar çeşitli yollarla kin duygusunu arttırmaktadır. $\mathrm{Bu}$ yollardan birincisi, doğal kaynaklara bağımlı olan ülkelerin kalkınma sürecinin bir parçası olarak geçici eşitsizliklerle karşılaşabilir. Bu durum, ekonominin farklı bölgelerinin farklı oranlarda büyümesine ve buna bağlı olarak refah dağılımında eşitsizliğe neden olabilir. Bu eşitsizlik kindarlığı artırabilir. Doğal kaynaklar her ne kadar ekonomik büyümeyi pozitif yönde etkilese de, doğal kaynaklar, özellikler de yer altı kaynakları, sahibi olan hükümet veya yatırımc1lar için büyük refah etkisine sahipken, toplumun geri kalanı için sadece az sayıda yeni iş imkanı sağlar. Bu farklılaşmış etki doğal kaynakların toplumun farklı kesimleri için farklı refah etkisi meydana getirdiği anlamina gelmektedir (Leamer vd., 1999; Spilimbergo vd., 1999). Doğal kaynakların adil olmayan bu dağılımı nispeten yoksul grupları devletin kontrolünü ele geçirmeye teşvik eder. Vatandaşların eşitsizlikle ilgili duygusal ve ideolojik öfkeleri şiddet içeren toplu eylemlere zemin hazırlar (Blattman ve Miguel, 2010, s.17). Örneğin, Nijeryada zenginliğin adil olmayan dağılımından kaynaklanan kızgınlıklar hükümete karşı ayaklanmanın nedenidir. Nijerya’da doğal gaz ve petrolden elde edilen gelirlerin \%80'i nüfusun \%1'ine giderken, nüfusun $\% 70$ 'i günlük $1 \$$ ile geçinmektedir. $\mathrm{Bu}$ eşitsizlik ülkedeki çok uluslu petrol şirketlerinin sömürgeci yapısı nedeniyle daha da şiddetlenmiștir. İngiliz petrol şirketi Shell, Nijerya'daki petrol çıkarma faaliyetleri sonucunda 30 milyar \$'dan fazla kar elde etmiş, ancak Nijer Delta bölgesi için önerilen köy geliştirme projesi başarılı olamamıştır. Hükümetin sorumluluktan kaçması ve hesap vermekten yoksun olması, Nijerya hükümetine karşı bir ayaklanmaya neden olmuştur. Nijerya'da yaşanan bir başka ayaklanmanın nedeni ise ekonomik olarak ülkenin kuzeyinin sahip olduğu uranyum zenginliğinden elde edilen gelire bağımlı olan merkezi hükümetin kuzeye çok az yatırım yapmasıdır (Humphreys, 2005, s.512).

İkincisi, doğal kaynakların yer altından çıkarılması için ihtiyaç duyulan işgücü nedeniyle, daha ucuz emek arz eden işgücü ve aileleri doğal kaynak zengini bu bölgelere göç edebilir. Bu göç yerleşikler aleyhine 
hem ekonomik refahı hem de demografik yapıyı bozmak suretiyle kindarlığı arttırır. Petrol çıkarma, madencilik veya ağaç kesme faaliyetlerini gerçekleştiren şirketler genellikle karşılığını tam olarak vermeksizin yöre halkının arazilerine el koymaktadırlar. Bu şirketlerin faaliyetleri içme suyunun kirlenmesi, ekilebilir arazilerin yok edilmesi, ağaçların kesilmesi, avlanma ve balıkçılık alanlarının yağmalanması gibi bir dizi çevresel soruna yol açmaktadır. Ayrıca daha önce ulaşımı zor olan bölgelere yolların yapılması, madencilerin, inşaat ve ağaç kesiminde çalışan işçilerin ve bazen de göçmen halkların bölgeye akın etmelerine neden olarak sosyal bozulmalara ve toplumsal gerginliklere yol açmaktadır. Tüm bu sorunlara ek olarak doğal kaynakların çıkarılma faaliyetlerinden daha çok merkezi hükümetler, çok uluslu şirketler ve çeşitli yabancı yatırımcılar gibi üçüncü ekonomik şahıslar ekonomik çıkar sağlamaktadır (Renner, 2002, s.39-40). Endonezya, Papua Yeni Gine ve Nijerya doğal kaynağın çıkarılma sürecinde ortaya çıkan çevresel tahribatlar, ekonomik eşitsizlik ve sosyal yabancılaşma sorunlarının neticesinde tetiklenen iç çatışmalara örnek teşkil eden ülkelerdir (Renner, 2002; International Crisis Group, 2001; Human Rights Watch, 1999).

Üçüncüsü, doğal kaynakların ekonomik krizler karşısında ekonomileri daha kırılgan getirerek, iç ayaklanmalar için uygun ortam oluşturması, iç savaş riskini arttırmasıdır. Doğal kaynaklara bağımlı ekonomilerde ihracat gelirleri genellikle birkaç emtiaya bağlıdır. Bu durum ticaret şoklarından mağdur olan gruplarda hoşnutsuzluğa neden olmaktadır (Humphreys, 2005, s.511). Örneğin, 1970 'den beri kritik hammaddelerin fiyatlarındaki oynaklık artmaktadır. Bu da hammadde zengini ülkelerin ekonomilerini ekonomik şoklara daha açık hale getirmektedir. Doğal kaynak fiyatlarındaki dalgalanmalar bu ülkelerin gelirlerinde de ani iniş ve çıkışlara neden olur ve mali disiplini bozar. Mali disiplinden sapmalar yolsuzluğa neden olurken, aynı zamanda devlet kurumlarının siyasi müdahaleden uzak kalma yeteneğini de zayıflatır. Yolsuzluk ve ortaya çıkan rantın dağılımı toplum kesimleri arasında rahatsızlık yaratır. Doğal kaynaklardan elde edilen rantların adil olmayan dağılımı, özellikle doğal kaynak zenginliğine sahip bölgelerin gelir akımlarından mahrum edilmeleri durumunda daha azı alan daha çoğu alana öfke duymaya başlar. Wantchekon (1999) doğal kaynaklardan elde edilen rantların adil olmayan dağılımından kaynaklanan öfkenin iç çatışmaları teşvik ettiğini ve istikrarsızlığa yol açmalarının muh- temel olduğunu ileri sürmektedir. Bu öfke refahın dağılımında kurumları etkisiz hale getirirken, hükümetleri daha da güçlendirmektedir. Hükümeti ele geçirme konusunda, diğerine duyulan kin güdüleyici olmaktadır. Bu durum, piyasa şoklarına maruz kalan doğal kaynak zengini devletleri iç ayaklanmalara karşı daha da savunmasız hale getirmektedir (Ross, 2003a, s.9).

Hangi nedenle ortaya çıkarsa çıksın artan ötekine duyulan kin doğal kaynak temelli silahlı iç çatışma riskini arttırmaktadır. Endonezyảnın Açe; Papua Yeni Gine’nin Bougainville; Nijeryảnın kuzey, Sudan’ın güney bölgelerinde yaşanan çatışmalar kindarlık temelli çatışmalardır (Lujala, 2010, s.18). Kindarlık bazen Endonezya’nın Açe ve Sudan'ın güney bölgelerinde olduğu gibi bölgesel özerklik taleplerinin; bazen Sierra Leone'da olduğu gibi yerel elitlerin görevlerini kötüye kullanmalarının bir sonucudur (Lujala ve Rustad, 2011, s.19). Kindarlık mekanizmasında ekonomik unsurlar kindarlığı körüklerken; siyasi ve sosyo-kültürel unsurlar kindarlığın şiddetini etkilemektedir (Collier ve Hoeffler, 2002a, Humphreys, 2003).

\section{Elverişlilik Mekanizması}

Ross (2004b) on beş iç savaşı incelemiş ve doğal kaynaklar ile iç ayaklanmaları ilişkilendiren iki mekanizmanın varlığına işaret etmiştir. Birincisi, doğal kaynaklar, özellikle komşu ülkelerden gelen, dış müdahaleyi tetiklemektedir. Bu mekanizmada komşu devletler doğal kaynaklara erişim elde etmek için isyancı grupları desteklemektedir. İkincisi, isyancı gruplar henüz ele geçirmedikleri, ancak gelecekte ele geçirmeyi umdukları, doğal kaynakların işletim haklarının önceden satışı yoluyla başlangıç maliyetlerini finanse etme gayreti içerisindedir. Bu mekanizmada dış güçler, isyancılar tarafından elde edilmeleri durumunda işletim hakları kendilerine verilecek olan doğal kaynakları için ileriye dönük ödeme yapmaktadır. Bu ödeme iç savaşın finansman sorununu önemli ölçüde aşmakta ve iç savaşa neden olmaktadır. $\mathrm{Bu}$ mekanizmada doğal kaynaklar, çeşitli nedenlerle başlamış olan ayaklanmaların finansmanında kullanılarak ayaklanmanın başarıya ulaşma beklentisini arttırmaktadır. Bu durum çatışma boyunca doğal kaynakların üretiminin kontrolü veya doğal kaynakların işletim haklarının önceden yabancı şirketlere veya yabancı devletlere satışıyla gerçekleşmektedir (Humphreys, 2005, s.512). 
İsyancı grupların henüz kontrol altına almadıkları, fakat savaşta ele geçirmeyi umdukları doğal kaynakların işletim haklarını satış yöntemi vadeli emtia piyasalarındaki sözleşmelere benzemektedir. Ancak vadeli emtia işlemlerinin gerçekleştiği piyasalar pek çok alıcı ve satıcının bulunduğu resmi, düzenli ve belirli merkezleri olan piyasalar olmasına karşın, savaş zamanında doğal kaynakların gelecekteki işletim haklarının satışının gerçekleştiği piyasalar gayrı resmidir ve genellikle de gizlidirler. Ayrıca sabit bir yeri olmayan bu piyasaların sadece birkaç aktörü bulunmaktadır (Ross, 2003a, s.22-23). Genellikle gizlilik içinde yürütülmelerinden ötürü doğal kaynakların gelecekteki işletim haklarının satışını belgelendirmek zordur. Ancak yine de 1989 ve 2004 yılları arasinda Liberya, Sierra Leone, Demokratik Kongo Cumhuriyeti, Kongo Cumhuriyeti ve Ekvator Ginesi gibi doğal kaynak zengini beş Afrika ülkesinde yaşanan iç savaşların ortaya çıkışları ve süreleri üzerinde bu tür satışların rol oynadıklarına ilişkin çeşitli kanıtlar bulunmaktadır. Angola'da ve Sierra Leone'de olduğu gibi Afrika'da yaşanan yakın zamanlardaki iç savaşlar boyunca ayaklanan grupların dışında hükümetler de silah ve asker temin etmek için böyle bir girişimde bulunmuştur. Bu tür girişimler neticesinde çatışmaların süresi uzamıştır (Ross, 2005, s.27-28).

\section{Zayıf Devlet Mekanizmaları}

Doğal kaynaklar ile iç savaşlar arasındaki ilişkiyi açıklayan yaygın mekanizmalardan biri de zayıf devlet mekanizmasıdır. Bu mekanizma, doğal kaynaklara bağımlı olan devletlerde doğal kaynaklardan elde ettikleri rantlara güvenen liderlerin vatandaşlarıyla karşılıklı bir yükümlülük geliştirememesine dayandirılmaktadır (Di John, 2007, s.963). Bu mekanizma doğal kaynaklardan elde edilen rantların ulusal ç1kar için kullanımı konusunda hükümetin kontrol ve denetiminin zayıflaması, elde edilen kamusal rantın sosyal çatışmaları çözme, eğitim ve sağlık gibi kamusal mal ve hizmetleri sağlamada kullanmaktan ziyade belli bir grup tarafından kontrol edilmesinden kaynaklanan ötekileşmeye duyulan kindarlığın bir ürünüdür (Ross, 2003a, s.10).

Sahip olunan doğal kaynak zenginliği hem ülkenin politik ekonomisini hem de yönetim biçimini etkiler (Karl, 1997; Ross, 1999). Bir ülke alüvyonlu değerli taşlar, koltan ve tanzanit gibi yüksek değerli doğal kaynaklara sahipse ve bu doğal kaynaklar küçük yat1rımlarla çıkarılabiliyorsa, madenciliğin yapıldığı bölgede devletin kanun ve düzen sağlaması zor olacaktır.
Hükümet otoritesinin zayıflığı bu bölgelerde hak sahiplerinin yasal tedbirler yoluyla mülkiyet haklarını korumalarını güçleştirecektir (Ross, 2003a, s.10-11). Ayrıca bu minerallerin sahip olduğu yüksek düzeydeki değer/ağırlık oranı vergilendirmelerini zorlaştıracak ve kaçakçılığın yapılmasını kolaylaştıracaktır. Söz konusu minerallerin sahip oldukları bu özellikler hükümet içinde yüksek düzeyde bir yozlaşmayı da beraberinde getirecektir (Reno, 1995; Ross, 2004b).

Gelirlerini doğal kaynaklardan elde eden hükümetler genellikle vergi gelirlerine güvenen hükümetlerden daha az demokratik ve daha az sorumludur. $\mathrm{Bu}$ ekonomilerde doğal kaynaklardan elde edilen gelir muhalefeti bastırmak, daha çok askeri harcamalar yapmak üzere kullanılır. Bu tip ülkelerde madencilik endüstrisi silahlı kuvvetlerin etki alanını genişletmesine yardımcı olduğu için maden endüstrileri ordu tarafindan kontrol edilir. Bu durum ordunun sivil hükümetten bağımsızlığının artmasına ve daha büyük etki alanına sahip olmasına yol açar. Örneğin Endonezya'da ordu petrol, doğal gaz ve maden şirketlerinden para tahsil etmektedir. Merkezi hükümetin standart bütçeleme işlemlerine tabi olmadıklarından, tahsil edilen bu paralar doğrudan ordunun bütçesine aktarılmaktadır. Yasama meclisinin ise bu paranın ne şekilde kullanıldığını denetleme yetkisi yoktur. Bu durum Endonezyada ordunun sivil hükümete karşı daha az hesap verir bir hale gelmesine neden olmakta ve Endonezyảnın kırılgan demokrasisini daha da zayıflatmaktadır (Ross, 2003a, s.14). Hegre (2002)'e göre doğal kaynak bağımlılığı yalnızca demokrasiye zarar vermekle kalmamakta aynı zamanda devletleri bir iç savaşa karşı daha savunmasız hale getirmektedir. Ayrıca demokratik olmayan bu hükümetlerin vatandaşların şikâyetlerini çözüme kavuşturmadaki başarısı da düşüktür (Ross, 2003a, s.14).

Humphreys (2005) doğal kaynakların çatışmalar üzerindeki etkisinin devlet kurumlarının gücüne bağlı olduğunu ileri sürmektedir. Doğal kaynak zengini zayıf devletlerde elit sınıf yolsuzluk ve asil-vekil ilişkileriyle gücünü korumaktadır. Fearon ve Laitin (2003)'e göre özellikle petrole bağımlı olan bu tür devletlerin güçlü siyasi kurumlara ve bürokrasiye sahip olma olasıllğ 1 çok düşüktür. Mahdavy (1970) bir hükümetin gücü büyük oranda halktan vergi alma kapasitesine bağlıdır. Bu kapasiteyi geliştirmede başarısız olan bir hükümetin etkin kamusal malları ve hizmetleri sağlayabilecek ve sosyal çatışmaları sslah edebilecek türde bir bürokrasi oluşturması mümkün değildir. 
Doğal kaynaklardan elde edilen rantlara olan bağımlılık yönetim biçiminin meşruiyeti ve ayaklanmaları önleme kapasitesi üzerinde olumsuz etkilere sahiptir. Birincisi doğal kaynaklardan elde edilen rantlara olan bağımlılık devleti vatandaşlarından bağımsız bir hale getirmektedir. Devletin vatandaşlarından bağımsız bir hale gelmesi devlet yöneticilerini daha yağma$\mathrm{c} 1$ hale getirebilmekte veya söz konusu yöneticilerin çıkar gruplarıyla uzun dönemli siyasi uzlaşma geliştirme ihtiyaçlarını azaltabilmektedir. Bu durum değişken olan doğal kaynak rantlarının aniden düşmesi durumunda vergi sistemini ve gelirleri öngörülemez hale getirmektedir. Doğal kaynaklardan elde edilen rantın devlet kapasitesi üzerindeki ikinci etkisi söz konusu rantların bürokratik kapasiteyi düşürebilmesidir. Vergilerden ziyade doğal kaynaklardan elde edilen rantlara bağımlı devletler, gelirlerini arttırmak için bürokratik araçlar geliştirme konusunda isteksiz olabilmektedir (Humphreys, 2005:519). Bu durum devleti isyancı gruplara karşı savunmasız bir hale getirebilmektedir. Üçüncüsü doğal kaynak zenginliğinin kötü bir şekilde yönetilmesi etnik temelli ayrılıkçı eğilimlerle birleştiğinde kindarlıklara yol açabilmekte ve bu kin Papua Yeni Gine, Nijerya ve Sudan'da olduğu gibi silahlı ayaklanma ihtimalini arttırabilmektedir (Malone ve Nitzschke, 2004, s.5).

Doğal kaynaklardan elde edilen ranta duyulan güven, devletleri zayıf formda kurumsallaşmaya itmektedir. Çünkü devlet harcamalarını finanse etme kolaylığı, hükümet yetkililerini güçlü kurumlar kurma konusunda motive etmeyecektir. Özellikle petrol gibi mineral kaynaklar bakımından zengin olan ülkeler sağlam bir bürokrasi inşa etmede genellikle başarısızdır. Çünkü bu ülkelerde mineral kaynaklardan elde edilen rantlara bel bağlanması, katı ve kısa görüşlü kararların alınmasına yol açmaktadır. Mineral kaynaklar bakımından zengin devletler kaçınılmaz olarak rantçı devletlere dönüşmektedir. Rantçı devletler de doğal kaynaklardan elde edilen rantların dağıtımı için ekonomik bağımlılıklar yaratarak; otoriteleri arac1lığıyla halk üzerinde siyasal ve sosyal anlamda denetim kurma arayışına girmektedir (Jones Luong ve Weinthal, 2006, s.38). Bu durum, barışçl muhalefet yolunu bloke ederken, kurumlar anlaşmazlıkları şiddete başvurmadan çözmeye muktedir olamamakta ve süreç şiddetli çatışmaları tetikleyebilmektedir (Jones Luong ve Weitnthal, 2006; Stiglitz, 2007).

\section{Seyrek Ticaret Ağı Mekanizması}

Doğal kaynaklara bağımlı ülkeler daha zayıf imalat sektörlerine ve daha düşük bir iç ticaret düzeyine sahiptir. İç ticaret, daha yüksek düzeyde sosyal bütünlük ve bölgelerarası bağımlılıkla ilişkili olduğundan imalat sektöründeki zayıflık ve ekonominin bağımsız üretim bölgelerine ayrılması çatışma riskini artırabilmektedir (Humphreys, 2005, s.513).

Liberal teorisyenlere göre ticaretin karşılıklı olarak kazançlı olduğu durumlarda ticaret ortaklarıyla savaşmak "ticari intihar"a kalkışmaktır. Bu argüman ticaret ortaklarının alış veriş aracılı̆̆ıyla birbirlerinin kültürünü daha iyi kavrayacaklarını iddia etmektedir. Siyaset felsefecileri ise ticaretin kültürleri değiştirmek suretiyle çatışma riskini azalttığını savunmaktadır. Ampirik çalışmalar birbirleriyle ticaret yapan devletlerin birbirleriyle çatışma riskinin daha az olduğunu göstermektedir (Doyle, 1997; Oneal and Russet, 1999). Buna karşın iç ticaretin yoğunluğuna veya iç şebekelerin planlanmasına ilişkin ülkeler arası ölçümler olmadığından uluslararası düzeyde test edilmiş, ancak bu hipotezin ülke bazlı geçerliliği test edilmemiştir (Humphreys, 2005, s.513).

\section{Sonuç}

Soğuk Savaş’in sona ermesi ve süper güçler arasındaki çatışmalarının ortadan kalkmasının ardından dünya barışını tehdit eden yeni bir tehlike olarak iç savaşlar gündeme gelmiştir. Tehlike boyutları giderek artan iç savaşların önlenmesi ve çözümlenmesi, günümüzün hızla küreselleşen dünyasında bir zorunluluk haline gelmiştir. İç savaşlara ilişkin etkin politikaların geliştirilmesi için ise öncelikle bu çatışmaların doğru analiz edilmesi zorunludur. Literatürde yer alan bazı çalışmalar siyasi, etnik ve dini faktörlerin dışında ekonomik faktörlerin de çatışma riski üzerinde önemli bir etkiye sahip olduğunu ileri sürmektedir. İç çatışmaların doğal kaynaklarla ilişkili olduğuna dair çok sayıda çalışma bulunmaktadır. Doğal kaynaklar ile iç savaşlar arasındaki ilişkiyi inceleyen çalışmaların büyük bir çoğunluğu söz konusu kaynakların iç savaş başlangıcı ve süresi üzerindeki etkilerini incelemektedir.

Doğal kaynak zenginliği ile iç savaş başlangıcı arasındaki ilişkiyi açıklayan altı farklı mekanizma mev- 
cuttur. Bu mekanizmalardan birincisi iç savaşların ayaklanma boyunca suç benzeri yağmalama faaliyetlerinden elde edilebilecek gelir ve devlet gelirlerinin kontrolünün ele geçirilmesini amaçlayan açgözlülük neticesinde ortaya çıktığını ileri süren açgözlü ayaklanma mekanizmalarıdır. İkincisi, doğal kaynak zenginliğinin yabancı devletler veya yabancı şirketler gibi devlet için üçüncü taraflar sayılanların iç savaşlara dâhil olmalarına veya destek vermelerine neden olduğunu iddia eden dışarıdan müdahale mekanizmasıdır. Üçüncüsü, iç savaşları eşitsizlikteki artış, ticaret şokları, doğal kaynakların çıkarılma süreçleri ve zenginliğin adil olmayan dağılımı olmak üzere dört argümanla açıklamaya çalışan kindarlık mekanizmalarıdır. Dördüncüsü, bazı durumlarda komşu devletlerin doğal kaynaklara erişim elde etmek ve dolaylı olarak faydalanmak için isyancı grupları bugün desteklemek suretiyle gelecekte isyancıların ele geçirmesini bekledikleri doğal kaynakların işletim haklarını bugünden satın almak için isyancıları finanse edebildiklerini ileri süren elverişlilik mekanizmasıdır. Beşincisi, doğal kaynaklardan elde edilen rantların hükümetlerin sosyal çatışmaları çözme, eğitim ve sağlık gibi kamusal mal ve hizmetleri sağlama istekliliklerini düşürerek hükümetleri zayıflatabildiğini öne süren zayıf devlet mekanizmalarıdır. Altıncısı, doğal kaynakların ülkelerin imalat sektörleri zayıflatacağı, bunun daha düşük iç ticaret düzeyine neden olacağ 1 ve bu düşük iç ticaretin sosyal bütünlük ve bölgelerarası bağımlılık ilişkisini zedeleyeceğini, üretimi bölgelerarası ayrıştıracağını ve bunun da iç savaş riskini arttıracağını iddia eden seyrek ăg mekanizmasıdır.

Mekanizmaların bolluğuna rağmen doğal kaynaklar ve iç savaşlar literatüründe genel kabul görmüş teorik bir çerçeve mevcut değildir. Bu eksiliğin ana sebebi veri eksikliği ve/veya varolan verilerin güvenilirliğidir. Araştırma konusunun naif olması, kayıtdışı11ğın yaygınlığı, faaliyetlerin ulusal veya uluslararası düzeyde gizlilik temelinde gerçekleşmesi ve devam etmesi, yasadışlık gözlem eksikliğine veya yetersizliğine neden olmaktadır. Gözlem yoksa veri yok, veri yoksa analiz yok, analiz yoksa politika yok cümlesine istinaden, literatürdeki çalışmalar çok parçalı, çok tekrarlı ve afaki politikalar ileri sürmenin ötesine gidememektedir. Siyaset bilimi açısından çok şey ifade eden konun, iktisadi boyutu çok büyük ve önemli olmasına rağmen çalışmalar hem teorik arka planı, hem ampirik boyutu hem de bulgulara dayalı somut politikalar önerme konusunda çok cılız kalmaktadır.
İç savaşlar ve doğal kaynaklar literatüründe diğer bir eksiklik ise bazı kaynaklarda adı geçen teorilere başka kaynaklarda hiç rastlanmaması ya da benzer teorilerin farklı araştırmalarda farklı, hatta bazen çelişir şekilde kullanılmasıdır. Farklı teorik temeller üzerine inşa edildiği ifade edilen yaklaşımlar bazen birbirleriyle iç içe, bazen ise birbirinin tekrarından öteye geçememektedir. Doğal kaynaklar ile iç savaşlar arasındaki ilişkiyi inceleyen mekanizmaları tek tek tespit etmek veya birbirinden tamamen bağımsız mekanizmalar olarak tanımlamak çok zordur.

Doğal kaynakların laneti hipotezini doğrulayan ve somut bulgular sunan çalışmalar olmasına rağmen değişkenler arası ilişkinin analiz bulguları değerlendirilirken dikkat edilmesi gereken iki husus vardır. Birincisi, doğal kaynakların iç savaşların tek sebebi olmadığıdır. İç çatışmaların her biri yoksulluk, etnik veya dini kindarlık ve istikrarsız hükümetler gibi pek çok karmaşık olgunun bir araya gelmesinin bir sonucudur. İkincisi, doğal kaynak zenginliğinin her zaman ve her yerde bir iç savaşa nedeni olmadığıdır. Hipotez her ne kadar Afrika ve Orta Asya ülkeleri için genel geçerliliğini korusa da, iç savaşlar hala nadir olaylardır. Doğal kaynaklar iç savaşların tek nedeni olmasa da araştırmalar bu kaynakların iç savaşların sonlandırılmasını geciktirdiğini, hatta çözümsüz hale getirdiğini göstermektedir.

\section{Kaynakça}

Basedau, M. and Lay, J. (2009). Resource Curse or Rentier Peace? The Ambigious Effects of Oil Wealth and Oil Dependence on Violent Conflict. Journal of Peace Research, 46 (6), 757-776.

Blattman, C. and Miguel, E. (2010). Civil War. Journal of Economic Literature, 48 (1), 3-57.

Boulding, Kenneth E. (1963). Conflict and Defence: A General Theory. New York: Harper \& Brothers.

Burton, J.W. (1997). Violence Explained: The Sources of Conflict, Violence, and Crime and Their Prevention, Manchester: Manchester University Press.

Collier, P. and Hoeffler, A. (1998). On Economic Causes of Civil War. Oxford Economic Papers, (50), 563-573. 
Collier, P. (2000). Rebellion as a Quasi-Criminal Activitiy. The Journal of Conflict Resolution, 44 (6), 839-853.

Collier, P. and Hoeffler, A. (2000). Greed and Grievance in Civil War. World Bank Policy Research Working Paper 2355, Available at: https://openknowledge. worldbank.org/bitstream/handle/10986/18853/ multi_page.pdf?sequence=1, (03.08.2016).

Collier, P. and Hoeffler, A. (2001). Data Issues in the Study of Conflict. Conference on Data Collection on Armed Conflict, Uppsala 8-9 June.

Collier, P. and Hoeffler, A. (2002a). On the Incidence of civil War in Africa. Journal of Conflict Resolution, 46 (1), 13-28.

Collier, P. and Hoeffler, A. (2002c). The Political Economy of Secession. Development Research Group, World Bank, Center for the Study of African Economies, Available at: https://core.ac.uk/download/ files/153/6464805.pdf, (04.03.2016).

Collier, P., Elliot, L., Hegre, H., Hoeffler, A., ReynolQuerol, M. and Sambanis, N. (2003). Breaking The Conflict Trap: Civil War and Development. Wahington, DC: World Bank and Oxford University Press.

Collier, P. and Hoeffler, A. (2004). Greed and Grievance in Civil War. Oxford Economic Papers, 56 (4), 563-596.

Collier, P. and Hoeffler, A. (2005). Resource Rents, Governance, and Conflict. Journal of Conflict Resolution. 49 (4), 625-633.

Cullen, A. (2005). Key Developments Affecting the Scope of Internal Armed Conflict in International Humanitarian Law. Military Law Review, 183, 69109.

Dashwood, S.H. (2000). Zimbabwe: The Political Economy of Transformation. Toronto. Canada: University of Toronto Press.
Di John, J. (2007). Oil Abundance and Violent Political Conflict: A Critical Assessment. Journal of Development Studies, 43(6), 961-986.

Doyle, M. (1997). Ways of War and Peace: Realism, Liberalism, and Socialism. New York: Norton.

Englebert, P. and Ron, J. (2004). Primary Commodities and War: Congo-Brazzaville's Ambivalent Resource Curse. Comparative Politics, 37(1):61-81.

Evans, G., and J. Newnham (2007). Uluslararası İlişkiler Sözlüğü. çev. H. Ahsen Utku, İstanbul: Gökkubbe.

Fearon, D. J. and Laitin, D. (2003). Ethnicity, Insurgency, and Civil War. American Political Science Review, 97 (1), 75-90.

Fearon, D.J. (2005). Primary Commodity Exports and Civil War. Journal of Conflict Resolution, 49 (4), 483-507.

Human Rights Watch, The Price of Oil: Corporate Responsibility and Human Rights Violations in Nigeria’s Oil Producing Communities, New York: January 1999.

Humphreys, M. (2005). Natural Resources, Conflict, and Conflict Resolution, Uncovering the Mechanisms. Journal of Conflict Resolution, 49 (4), 508537.

İnat, K., Gieler, W (2007). Kongo Demokratik Cumhuriyeti (Zaire): Birinci Afrika Dünya Savaşı. Dünya Çatışma Bölgeleri (ed.: K. İnat- B. Duran- M. Ataman), Ankara: Nobel.

International Crisis Group, Indonesia: Natural Resources and Law Enforcement, ICG Asia Report No: 29, Jakarta and Brussels, 20 December 2001, pp.1018.

Jeong, H. (2008). Understanding Conflict and Conflict Analysis. Los Angeles: SAGE. 
Jones Luong, P. and Weinthal, E. (2006). Rethinking the Resource Curse: Ownership Structure, Institutional Capacity, and Domestic Constraints. Annual Review of Political Science, 9, 241-263.

Karl, T. L. (1997). The Paradox of Plenty: Oil Booms and Petro-States. Berkeley, CA: University of California Press.

Keen, D. (1998). The Economic Functions of Violence in Civil Wars. Adelphi Paper 320, New York: Oxford University Press.

Leamer, E. E., Maul, H., Rodriguez, S. and Schott, P.K. (1999). Does Natural Resource Abundance Increase Latin American Income Inequality. Journal of Development Economics, 59, 3-42.

Lee, J., D. Ashmore and D. Wilder, (2001). Social Identity and Intergroup Conflict: Introduction. Lee, J., D. Ashmore and D. Wilder (ed.). Social Identity and Intergroup Conflict. New York: Oxford University Press.

Le Billon, P. (2001). The Political Ecology of War: Natural Resources and Armed Conflict. Political Geography, 20 (5), 561-84.

Lootsteen, Y.M. (2000). The Concept of Belligerency in International Law. Military Law Review 166, 109141.

Lujala, P. (2010). The Spoils of Nature: Armed Civil Conflict and Rebel Access to Natural Resources. Journal of Peace Research, 47 (1), 15-28.

Lujala, P. and Rustad, S.A. (2011). High-value Natural Resources: A Blessing or a Curse for Peace?. Sustainable Development Law \& Policy, 12 (1), 19-57.

Mahdavy, H., (1970). The Patterns and Problems of Economic Development in Rentier States: The Case of Iran. in Studies in Economic History of the Middle East, ed. M. A. Cook, London: Oxford University Press.
Malone, D. and Nitzschke, H., (2004). Economic Agendas in Civil Wars: What We Know, What We Need to Know, WIDER Discussion Paper No. 2005/07 (Helsinki: WIDER).

Malthus, T. (1798). An Essay on the Principle of Population. New York: Penguin (1970 edition).

Marshall, G. (1999). Sosyoloji Sözlügüu. Çev. Derya Kömürcü, Osman Akınhay, Ankara: Bilim ve Sanat.

Meldrum, A. (2000). Good-bye, New Republic OnLine, April 17.

Mengiler, Ö. (2005). Birleşmiş Milletler Çerçevesinde Uluslararası Uyuşmazlıkların Barışçı Çözümü. Ankara: Platin.

Mial, H., O. Ramsbotham and Woodhouse, T. (2007). Contemporary Conflict Resolution: The Prevention, Management and Transformation of Deadly Conflicts. Cambridge: Polity Press.

Morrison, K.M., (2010). Oil, Conflict, and Stability, Working Paper, Cornell University.

Oneal, J., B Russett. (1999). Assessing the liberal peace with alternative specifications: Trade still reduces conflict. Journal of Peace Research, 36 (4): 423-32.

Öğüt, S. (2013). Uluslararası Hukuk Açısından Suriye. İstanbul: DÜBAM.

Pazarc1, H. (1994). Uluslararası Hukuk Dersleri. III. Kitap, Ankara: Turhan.

Renner, M., (2002). The Anatomy of Resource Wars, World Watch Paper, No:162, Washington, DC: World Watch Institute.

Reno, W. (1995). Corruption and State Politics in Sierra Leone. New York: Cambridge University Press.

Ross, M. L. (1999). The Political Economy of the Resource Curse. World Politics, 51 (2), 297-322. 
Ross, M. L. (2003a). Natural Resources and Civil War: An Overview, World Bank Research Observer, Available at: http://www.unepfi.org/fileadmin/documents/conflict/ross_2003.pdf, (19.08.2016).

Ross, M. L. (2003b). Oil, Drugs, and Diamonds: The Varying Roles of Natural Resources in Civil War, In The Political Economy of Armed Conflict: Beyond Greed and Grievance (eds. K. Ballentine and J. Sherman), Lynee Rienner Publishers: Boulder.

Ross, M. L. (2003c). "How Does Mineral Wealth Affect the Poor?", Working Paper, UCLA, Available at: www.polisci.ucla.edu/faculty/ross/minpoor.pdf, (18.08.2016).

Ross, M. (2004a). What Do We Know About Natural Resources and Civil War?. Journal of Peace Research, 41 (3), 337-56.

Ross, M. (2004b). How Do Natural Resources Influence Civil War? Evidence from Thirteen Cases. International Organization, 58 (1), 35-67.

Ross, M. (2005). Booty Futures, Unpublished Working Paper, Department of Political Science, University of California, Los Angeles, pp.1-30.

Smith, B., (2004), Oil Wealth and Regime Survival in the Developing World, 1960-1999. American Journal of Political Science, 48(2), 232-246.

Spilimbergo, A., Londono, J. L., and Szekely, M. (1999). Income Distribution, Factor Endowments, and Trade Openness. Journal of Development Economics, 59 (1), 77-101.
Stiglitz, J. E., (2007). What is the Role of the State?. In Macartan Humphreys, Jeffrey D. Sachs \& Joseph E. Stiglitz (eds.), Escaping the Resource Curse. New York: Columbia University Press.

UN Panel of Experts (2000), "Report of the Panel of Experts Appointed Pursuant to Security Council Resolution 1306 (2000), Paragraph 19, in Relation to Sierra Leone," United Nations Security Council S/2000/1195, Available at: https://mondediplo. com/IMG/pdf/un-report.pdf, (22.06.2016).

UN Panel of Experts (2001), "Report of the Panel of Experts on the Illegal Exploitation of Natural Resources and Other Forms of Wealth of the Democratic Republic of Congo (S/2001/357)," United Nations Security Council, Available at: https://documentsdds-ny.un.org/doc/UNDOC/GEN/N01/323/54/ IMG/N0132354.pdf?OpenElement, (22.06.2016).

Wantchekon, L., (1999), Why Do Resource Abundant Countries Have Authoritarian Goverments? Yale University Leitner Center Working $\mathrm{Pa}$ per 99-12, Available at: https://www.princeton. edu/ lwantche/Why_Do_Resource_Dependent_ Countries_Have_Authoritarian_Governments, (24.08.2016).

Wilson, H.A. (1988). International Law and Use of Force by National Liberation Movements. Oxford: Clarendon Press. 